Revue bibliographique pour le domaine irano-aryen

\title{
Denise Aigle. The Mongol Empire between Myth and Reality: Studies in Anthropological History
}

\section{Patrick Wing}

\section{Q OpenEdition}

1 Journals

\section{Electronic version}

URL: http://journals.openedition.org/abstractairanica/47147

DOI: 10.4000/abstractairanica.47147

ISBN: 1961-960X

ISSN: 1961-960X

Publisher:

CNRS (UMR 7528 Mondes iraniens et indiens), Éditions de l'IFRI

Electronic reference

Patrick Wing, « Denise Aigle. The Mongol Empire between Myth and Reality: Studies in Anthropological History ", Abstracta Iranica [Online], Volume 37-38-39 | 2018, document 8, Online since 30 December 2018, connection on 26 September 2020. URL : http://journals.openedition.org/abstractairanica/ 47147 ; DOI : https://doi.org/10.4000/abstractairanica.47147

This text was automatically generated on 26 September 2020

Tous droits réservés 


\title{
Denise Aigle. The Mongol Empire between Myth and Reality: Studies in Anthropological History
}

\author{
Patrick Wing
}

\section{REFERENCES}

Denise Aigle. The Mongol Empire between Myth and Reality: Studies in Anthropological History. Leiden: Brill, 2014, 393 p. Maps, genealogical tables, illustrations.

1 In this work, Denise Aigle endeavors to highlight the complex layers of interpretation of the past and transmission of historical writing about the Mongol Empire, and particularly the Mongols in Iran during the rule of the Ilkhanate (1258-1335). The book stands as a major contribution to our understanding of the production of knowledge about the Mongols, and a reminder that historical sources are produced by individuals who seek to render the past and present understandable in terms that are culturally familiar.

2 The book is divided into four thematic parts, each comprising between two and four chapters. There are thirteen chapters in total, in addition to an Introduction and an Epilogue. Nine of the chapters are expanded and updated versions of articles previously published elsewhere between 2000 and 2011. Part 1, titled "The Memoria of the Mongols in Historical and Literary Sources," examines the ways in which cultural expectations and the forms of history writing about the Mongols by the peoples they encountered shaped historical narrative. Part 2, titled "Shamanism and History," is comprised of three chapters, all exploring the encounter between Mongol and Muslim culture, and the ways in which non-Mongol authors have interpreted Mongol religion, origins, and law. Part 3, "Conquering the World Protected by the Tenggeri," consists of two chapters, dealing with the relations between the Mongols and the Latin West on one hand, and with the Ayyubid rulers of Syria on the other. Part 4, "Mamluks and Ilkhans. 
The Quest of Legitimacy," deals with the ways in which the question of legitimate political authority informed the conflict between the Ilkhans and the Mamluks, from the 1260 s through the first decade of the $14^{\text {th }}$ century.

3 This book will challenge scholars of the history of the Mongols in the Middle East to not take lightly questions of authorship, translation, transmission, and interpretation of the historical record. In Aigle's final analysis, the space between myth and reality is the historical record itself, one-part fact, one-part memory, and sifted through an array of cultural symbols and narratives. As the author shows clearly, any attempt to understand the history of the Mongol Empire without considering these complex issues of culture and memory is bound to reveal only part of the story.

\section{AUTHORS}

\section{PATRICK WING}

University of Redlands 